\title{
Abstraction of arsenic(III) on activated carbon prepared from Dialium guineense seed shell: kinetics, isotherms and thermodynamic studies
}

\author{
Julius U. Ani ${ }^{1} \cdot$ Alfred E. Ochonogor $^{1} \cdot$ Kovo G. Akpomie $^{1} \cdot$ Chisom S. Olikagu $^{1} \cdot$ Charles C. Igboanugo $^{1}$
}

(c) Springer Nature Switzerland AG 2019

\begin{abstract}
Removal of arsenic(III) from aqueous solution has been studied using activated carbon produced from Dialium guineense seed shell by impregnation of carbonized sample with zinc chloride and thermal activation. The zinc chloride activated sample was selected because it produced the highest iodine number, $\mathrm{mg} / \mathrm{g}$ (962.52) compared to the raw sample (601.57), phosphoric acid and nitric acid impregnated samples $(802.10,868.95)$. Proximate analysis of raw $D$. guineense seed shell revealed low ash content of $1.70 \%$ and moderate fixed carbon of $32.97 \%$. The prepared adsorbent was characterized using Brunaeur-Emmett-Teller surface area, SEM and FTIR analyses. The surface area of the zinc chloride activated adsorbent was $533.94 \mathrm{~m}^{2} / \mathrm{g}$ and its micropore volume $0.475 \mathrm{~cm}^{3} / \mathrm{g}$, with a porous structure that is well organized. Batch adsorption experiments were done by changing the following parameters: adsorbent dose, $\mathrm{pH}$, contact time, initial metal ion concentration and temperature. Adsorption increased as each parameter was varied but decreased with increase in initial arsenic(III) concentration. The Freundlich model presented better fit with $\mathrm{R}^{2}$ of 0.998 compared to the Freundlich isotherm (0.991) and Tempkin isotherm (0.984). The positive value of $\Delta H^{\circ} 51.68 \mathrm{~kJ} / \mathrm{mol}$ showed the endothermic nature of adsorption. The study demonstrated the potential of $D$. guineense seed shell as low cost adsorbent for removing arsenic(III) from polluted water.
\end{abstract}

Keywords Dialium guineense seed shell · Impregnation · Carbonization · Aqueous solution · Arsenic(III) Endothermic

\section{Introduction}

Arsenic is a steel-gray, brittle, toxic, non-degradable heavy metal, exists in nature in different oxidation states, the most frequent oxidation states are - III (arsines), zero (arsenic), + III (arsenite), and + V (arsenate). The mostly available forms of As in water are the inorganic species arsenate $[\mathrm{As}(\mathrm{V})]$ and arsenite $[\mathrm{As}(\mathrm{III})]$. The $\mathrm{As}(\mathrm{V})$ species occurs as oxyanions $\left(\mathrm{H}_{2} \mathrm{AsO}_{4}{ }^{-}\right.$and $\left.\mathrm{HAsO}_{4}{ }^{2-}\right)$ at neutral $\mathrm{pH}$, while the arsenic(III) species is neutral $\mathrm{H}_{3} \mathrm{AsO}_{3}$ [1-3]. As(III) is more toxic and more difficult to remove by physico-chemical treatment than $\mathrm{As}(\mathrm{V})$ [4]. The presence of arsenic in water is due to many anthropogenic activities such as natural weathering processes, geochemical reactions, combustion of fossil fuels, volcanic eruptions, gold mining, leaching of arsenic compounds, smelting of metal ores, desiccants, wood preservatives and pesticides [5]. Prolonged exposure to arsenic causes skin cancer [6], lung, bladder and kidney cancer [7], hypertension, diabetes mellitus, hepatomegaly and injury to central nervous system, muscular weakness and neurological disorder [8]. As far back as 1860, arsenic compounds were used extensively as pesticides to destroy rodents, insects and fungi, due to their toxicity. The toxicity was said to arise from the ability of arsenic to react with sulphydryl (-SH) group of enzyme thereby preventing the action of thiol (R-SH) groups responsible for enzyme activity [9]. The arsenic concentration of $0.01 \mathrm{mg} / \mathrm{l}$ has been set by World Health Organization (WHO) as the upper permissible limit in areas where less water is consumed whereas in tropical areas it could rise up to $0.05 \mathrm{mg} / \mathrm{l}$. Concentrations higher than the upper

Julius U. Ani, julius.ani@unn.edu.ng | 1 Department of Pure and Industrial Chemistry, University of Nigeria, Nsukka, Nigeria.

SN Applied Sciences (2019) 1:1304 | https://doi.org/10.1007/s42452-019-1335-1 
permissible limit can cause its deposition in human body [10]. The adulteration of ground water by arsenic has been reported from many countries of the world. For instance, Egbinola and Amanambu [11], has reported that arsenic contamination in ground/drinking water ranged from 0.0 to $0.14 \mathrm{mg} / \mathrm{l}$ in samples collected at the end of rainy season in Ibadan, Nigeria. The concentration range is more than the WHO permissible limit for arsenic. Therefore, removal of arsenic from drinking water has drawn attention and proved to be a major concern in many water utilities in Nigeria.

To treat arsenic in water bodies' coagulation and precipitation, cation exchange, adsorption, lime softening, and reverse osmosis have been applied. Adsorption is often used because it is very simple and cost effective [12]. Numerous adsorbents have been used for the sequestration of heavy metals from polluted water such as activated carbon, agricultural biomass materials, nanoparticles, activated alumina, sandy soils, hydrous zirconium oxide, lanthanum-loaded-silica gel, hematite, goethite, magnetite, feldspar, clays and metal-loaded coral limestone [13-18]. Most of these adsorbents are expensive and difficult to regenerate. Consequently, there is need to develop low cost adsorbents which are locally available and environmentally friendly. The aim of this study was to prepare activated carbon adsorbent from raw Dialium guineense seed shell (RDGSS), an agricultural byproduct also known as tamarind seed shell, and to study its potential for removing arsenic(III) from aqueous solution. The objectives of the work were to prepare and characterize activated carbon adsorbent from $D$. guineense seed shell, investigate the effect of contact time, adsorbent dose, initial concentration of the adsorbate, temperature and $\mathrm{pH}$ of adsorption, and study the kinetic, isotherms and thermodynamic of the adsorption.

\section{Materials and methods}

\subsection{Adsorbate preparation}

A stock solution of As(III) (1000 mg/l) was prepared by dissolving $1.320 \mathrm{~g}$ arsenic trioxide in de-ionized water containing $25 \mathrm{ml} 1 \mathrm{M}$ sodium hydroxide diluted to $1 \mathrm{I}$ [5]. The mixture was then diluted to $100 \mathrm{ml}$ with de-ionized water. 2 drops of phenolphthalein was added to the solution after which it was titrated with $1 \mathrm{M} \mathrm{HCl}$ until it became neutral. The neutral solution was transferred into a $1000 \mathrm{ml}$ volumetric flask and made up to mark using de-ionized water. Standard arsenic(III) solutions were prepared by serial dilution of stock solution with de-ionized water. All chemicals were of analytical grade.

\subsection{Adsorbent preparation}

Dialium guineense seed shells were collected from Ogige market in Nsukka, Nigeria and crushed into a mixture of various granular sizes. The crushed material was sieved using $0.6 \mathrm{~mm}$ sieve to produce nearly uniform sized mixture which was stored in plastic bottle for carbonization. Carbonization of the sieved material was carried out in a muffle furnace (Vectsar model LF 3 UK) at $250^{\circ} \mathrm{C}$ for $30 \mathrm{~min} .120 \mathrm{~g}$ of the carbonized sample was subsequently separated into three portions (A, B and C) and soaked in (40\%) phosphoric acid, zinc chloride and nitric acid, respectively at the ratio of 1:1 for $24 \mathrm{~h}$. Each sample was filtered and the residue was placed in the muffle furnace by use of a crucible. The samples were heated to activation temperature of $400^{\circ} \mathrm{C}$ for $30 \mathrm{~min}$. Carbonized samples were washed with de-ionized water till a neutral $\mathrm{pH}$ was obtained after which they were dried at $110^{\circ} \mathrm{C}$ for $6 \mathrm{~h}$ and then stored in a desiccator.

\subsection{Adsorbent characterization}

\subsubsection{Fourier transform infrared analysis}

The prepared adsorbent samples were examined using Fourier transform infrared (FTIR) spectrophotometer (Model Agilent Technologies) with range $650-4000 \mathrm{~cm}^{-1}$. FTIR spectra were recorded using FTIR spectrophotometer.

\subsubsection{Scanning electron microscopy}

The textural and surface morphology of the adsorbents were studied by scanning electron microscopy (SEM).

\subsection{Proximate analyses}

Proximate analyses of activated carbon are those properties which are classified as moisture content, volatile matter, ash content and fixed carbon. The proximate analyses of $D$. guineense seed shell were determined by standard methods adapted from the work of Billy et al. [19] and Menkiti et al. [20] for moisture and ash contents respectively. The determination of volatile matter was carried out by placing $3.0 \mathrm{~g}$ of dried raw $D$. guineense seed shell (RDGSS) sample in a preweighed crucible, heated in a muffle furnace (Vectar model LF 3 UK) at $400^{\circ} \mathrm{C}$ for $45 \mathrm{~min}$. The percent volatile matter was calculated using Eq. (1).

$\%$ Volatile matter $=\frac{\text { Loss in weight of dried RDGSS }}{\text { Weight of RDGSS before heating to } 400^{\circ} \mathrm{C}} \times 100$

The fixed carbon content was obtained by difference:

$\%$ Fixed carbon $=100-($ moisture + ash + volatile matter $) \%$ 


\section{5 lodine number}

The iodine number was determined by method of Budinova et al. [21]. $0.5 \mathrm{~g}$ of each sample was put into a $250 \mathrm{ml}$ conical flask and then $10 \mathrm{ml}$ of $5 \% \mathrm{HCl}$ and $100 \mathrm{ml}$ of $0.1 \mathrm{~N}$ iodine solutions were added into the conical flask. The mixture was stirred for $15 \mathrm{~min}$ after which it was filtered. $50 \mathrm{ml}$ of the filtrate was titrated against $0.1 \mathrm{~N}$ sodium thiosulphate solution using starch indicator. lodine number was evaluated using Eq. 3.

$I=\frac{V_{1}\left(V_{3}-V_{2}\right) 127 N}{V_{3} m}$

where $V_{1}$, volume of iodine solution to be titrated; $V_{2}$, volume of thiosulphate spent on titration of iodine with activated carbon; $V_{3}$, volume of thiosulphate spent on titration of iodine without activated carbon; $\mathrm{N}$, normality of iodine solution and $m$, mass of sample.

\subsection{Pore size and surface area of activated carbons}

The pore size and surface area of different activated carbon (AC) samples were measured by $\mathrm{N}_{2}$ adsorption at $77 \mathrm{~K}$ using Quantachrome Instruments, Version 11.03.

\subsection{Adsorption study}

Batch adsorption was carried out according to method of Budinova et al. [21]. The experiment involved mixing $25 \mathrm{ml}$ of As(III) solution of the desired concentration with a known dose of $A C$ at specific $\mathrm{pH}$ and $30^{\circ} \mathrm{C}$. To study the effect of contact time, $0.1 \mathrm{~g}$ adsorbent was mixed with $25 \mathrm{ml}$ of As(III) solution $100 \mathrm{mg} / \mathrm{l}$ concentration and $\mathrm{pH}$ of 6.0 , in $100 \mathrm{ml}$ beaker for varying contact time of 5-90 min. For the effect of initial As(III) concentration study, $0.1 \mathrm{~g}$ of adsorbent was mixed with $25 \mathrm{ml}$ of As(III) solution of varying concentrations (50-200 mg/l), pH 6.0 and contact time $25 \mathrm{~min}$. To study the effect of $\mathrm{pH}, 0.1 \mathrm{~g}$ adsorbent was mixed with $25 \mathrm{ml}$ of $\mathrm{As}$ (III) solution $100 \mathrm{mg} / \mathrm{l}$ and varying $\mathrm{pH}$ of $2.5-10.0$. For the effect of adsorbent dose, varying dose $(0.05-0.25 \mathrm{~g})$ of adsorbent was mixed with $25 \mathrm{ml}$ of As(III) solution $100 \mathrm{mg} / \mathrm{l}$ concentration and $\mathrm{pH}$ 6.0. Each sample was agitated for a period of time at constant speed using magnetic stirrer (78 $\mathrm{HW}$ model). The sample was filtered and the concentration of As(III) in the filtrate determined by Atomic Absorption Spectrophotometer (Agilent FS 240 AA USA). The percentage removal of As(III) was calculated using the following relationship:

$\%$ As(III) Removal $=\frac{C_{o}-C_{e}}{C_{o}} \times 100$ where $C_{o}$ and $C_{e}$ are the initial and final (equilibrium) concentrations of $\mathrm{As}(\mathrm{III})(\mathrm{mg} / \mathrm{l})$, respectively. The amount of adsorption at any time, $q_{e}(\mathrm{mg} / \mathrm{g})$, was calculated by:

$q_{e}=\frac{\left(C_{o}-C_{e}\right) V}{W}$

$\mathrm{V}$ is the volume of the test solution (I) and $\mathrm{W}$ is the mass of adsorbent used (g).

\section{Results and discussion}

\subsection{Results of adsorbent characterization}

The FTIR analysis of the raw and activated carbon produced adsorbents is shown in Fig. 1. The FTIR helps to relate the functional groups available on the adsorbent which could interact efficiently with heavy metal ions in solution, predicting to a reasonable extent the effectiveness of the adsorbent. The spectrum of the raw biomass showed the presence of $-\mathrm{OH}$ groups by bands at $3295 \mathrm{~cm}^{-1}$. The aliphatic organic $\mathrm{CH}_{3}$ stretching was indicated by absorptions at 2922 and $2851 \mathrm{~cm}^{-1}$ [22]. Prominent $C=O$ stretching vibrations were observed at 1606 and $1520 \mathrm{~cm}^{-1}$ while the $\mathrm{C}=\mathrm{C}$ of alkenes at $1438 \mathrm{~cm}^{-1}$. The primary alcoholic $\mathrm{C}-\mathrm{O}$ stretching was indicated by the band at $1032 \mathrm{~cm}^{-1}$ [14]. The FTIR spectrum of the activated carbon showed significant band changes from the raw biosorbent and the disappearance of most of the organic bands which indicate the successful production of activated carbon from the biosorbent.

The scanning electron micrographs of raw $D$. guineense seed shell and zinc chloride activated $D$. guineense seed shell are shown in Fig. 2. The surface of the raw $D$. guineense seed shell exhibited many large sheets of layers within and had almost no porous structure. This is as a result of agglomeration and migration of inorganic matter to the surface causing pore blockage. Scanning electron micrograph of the zinc chloride activated $D$. guineense seed shell showed a well developed and organized porous structure compared to raw D. guineense seed shell. Activation process does not only result to creation of pores but leads to substantial removal of inorganic material and some other impurities which could inhibit good pore structure development [23].

Table 1 gives the proximate properties of raw $D$. guineense seed shell. The possession of low ash content (1.70\%) and a fixed carbon content of $32.97 \%$ makes $D$. guineense seed shell suitable as activated carbon precursor. The ash content of $D$. guineense as obtained in this work $(1.70 \%)$ is much lower than the ash content obtained for sugar cane bagasse $(27.93 \%)$ and corn husk (28.81\%) reported in an investigation by Guan et al. [24]. 
Fig. 1 FTIR spectra of a raw $D$. guineense seed shell, $\mathbf{b}$ zinc chloride activated $D$. guineense seed shell
Fig. 2 Scanning electron micrographs of a raw $D$. guineense seed shell, $\mathbf{b}$ zinc chloride activated $D$. guineense seed shell
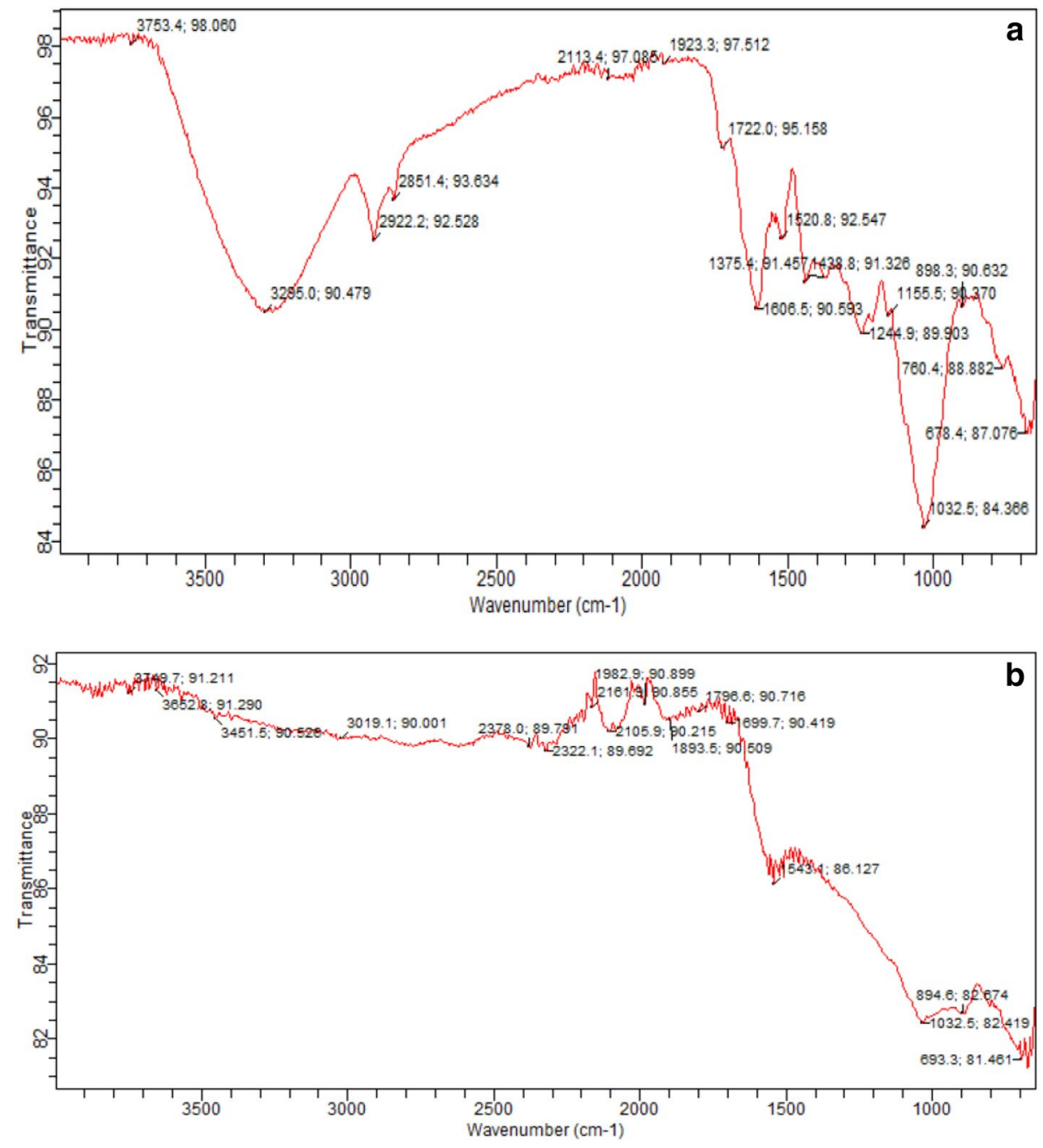

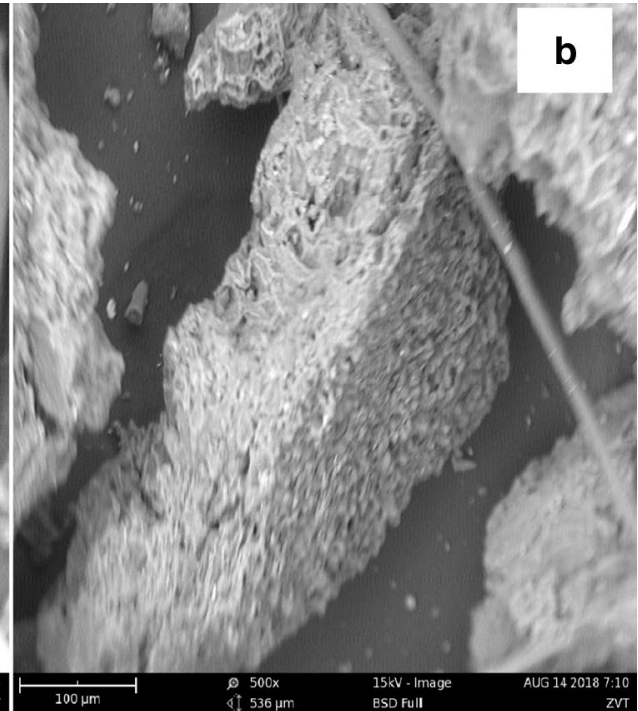

Table 2 presents the iodine number of the studied materials namely raw $D$. guineense seed shell, carbonized $D$. guineense seed shell, zinc chloride activated $D$. guineense seed shell, phosphoric acid activated $D$. guineense seed shell and nitric acid activated $D$. guineense seed shell. The amount of iodine removed by activated carbon is an

\section{SN Applied Sciences}


Table 1 Properties of raw $D$. guineense seed shell

\begin{tabular}{lr}
\hline Property (wt \%) & Value \\
\hline Moisture content & 6.00 \\
Ash content & 1.70 \\
Volatile matter & 59.33 \\
Fixed carbon & 32.97 \\
\hline
\end{tabular}

Table 2 lodine number of raw $D$. guineense seed shell, carbonized $D$. guineense seed shell, zinc chloride activated $D$. guineense seed shell, phosphoric acid activated $D$. guineense seed shell and nitric acid activated $D$. guineense seed shell

\begin{tabular}{ll}
\hline Material & $\begin{array}{l}\text { lodine } \\
\text { number } \\
(\mathrm{mg} / \mathrm{g})\end{array}$ \\
\hline Raw Dialium guineense seed shell & 521.37 \\
Carbonized Dialium guineense seed shell & 601.57 \\
Zinc chloride activated Dialium guineense seed shell & 962.52 \\
$\begin{array}{l}\text { Phosphoric acid activated Dialium guineense seed } \\
\text { shell }\end{array}$ & 802.10 \\
Nitric acid activated Dialium guineense seed shell & 868.95 \\
\hline
\end{tabular}

indication of its ability to adsorb low molecular weight compounds. Carbons that can remove a high percentage of iodine normally have high surface area [25]. When the amount of iodine adsorbed is high it suggests that the surface area and the mesoporous structure will be large. Zinc chloride activated $D$. guineense seed shell was selected for adsorption study among the others because it produced the highest iodine number $(962.52 \mathrm{mg} / \mathrm{g})$.

The BET surface area and micropore volume of zinc chloride activated $D$. guineense seed shell were $533.943 \mathrm{~m}^{2} / \mathrm{g}$ and $0.475 \mathrm{~cm}^{3} / \mathrm{g}$, respectively. Surface areas of commercial activated carbon are in the range of $400-500 \mathrm{~m}^{2} / \mathrm{g}$ while micropore volumes of agro waste activated carbons are reported to be between 0.1 and $0.6 \mathrm{~cm}^{3} / \mathrm{g}$ [25].

\subsection{Influence of adsorption variables}

Figure 3a-e show the effect of adsorption parameters on the adsorption of arsenic(III) on zinc chloride activated $D$. guineense seed shell. The amount of solute $(\mathrm{Ce})$ that remains in the effluent decreases with increase of time (Fig. 3a), adsorbent dose (Fig. 3b), temperature (Fig. 3d) and $\mathrm{pH}$ (Fig. 3e) whereas it increases with increase in initial metal concentration (Fig. 3c). Each curve gave a characteristic sigmoid shape with varying degree of steepness and breakthrough for As(III) removal. The percent removal of As(III) initially increased rapidly (5-20 min) and then slowed down gradually when equilibrium was approached (Fig. 3a). This can be explained by the strong attraction forces between the positive sites of cationic As(III) and the anionic sites of the activated carbon.

The effect of adsorbent dose was studied at $30^{\circ} \mathrm{C}$ by studying the sorbent amount from $(0.05-0.25 \mathrm{~g}) / 25 \mathrm{ml}$. Figure $3 \mathrm{~b}$ shows that there was slight increase in arsenic(III) removal initially from $0.05 \mathrm{~g}(78 \%)$ to $0.15 \mathrm{~g}(79 \%)$ before a rapid rise was recorded. The reason may be due to increasing availability of surface active sites resulting from the increased dose of adsorbent [26].

The percent removal of arsenic(III) was found to decrease as initial arsenic concentration increased (Fig. 3c). It can be explained that the active sites on the adsorbent for adsorbate removal decreases when As(III) concentration increases. Hence, there was lack of available active sites required for the high concentration of As(III). Similar results were reported [27-30].

Influence of temperature on equilibrium sorption capacity of adsorbent for arsenic was investigated at the temperature range of $30-75^{\circ} \mathrm{C}$ at an initial arsenic concentration of $100 \mathrm{mg} / \mathrm{l}$ (Fig. 3d). The rate of reaction between adsorbent and adsorbate in water is influenced by temperature. The rate at which adsorbate molecules diffuse increases rapidly across the external boundary layer and inside the pores of adsorbent as temperature increased but tended to decrease at $60^{\circ} \mathrm{C}$. The reason for the decrease may be due to the destruction of active sites in the activated carbon as temperature increased. At higher temperatures, the mobility of metal ions increases and the adsorption is endothermic [31].

The arsenic removal increased with increase in $\mathrm{pH}$ (Fig. 3e). The concentration of As(III) adsorbed at low pH was relatively low, due to the protonation of most donating groups, especially $\mathrm{OH}$ groups of the adsorbent. The reaction of the adsorbent and the metal cation involved the lone pair electrons of the oxygen and the metal cation vacant orbitals. The concentration of $\mathrm{H}^{+}$was very high at low $\mathrm{pH}$ when compared to the metal cation allowing the oxygen lone pair to preferentially coordinate with the $\mathrm{H}^{+}$. Also the smaller size of the $\mathrm{H}^{+}$facilitated the interactions. At high pH (more than 4) $\mathrm{H}^{+}$available allowed for deprotonation. There was an increase of negative charges on the adsorbent surface. Therefore the oxygen lone pair reaction with the metal cation dominated [32].

\subsection{Adsorption kinetics results}

Figure $3 a$, $b$ show the pseudo-first order and pseudosecond order plots of the adsorption of As(III) onto zinc chloride activated $D$. guineense seed shell. Plotting In(qeqt) versus time produced a curve showing that the integral uptake of As(III) was fast around the first 20 min then the adsorption remained steady. The $\mathrm{R}^{2}$ value for the pseudo-

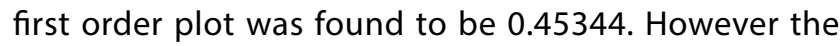



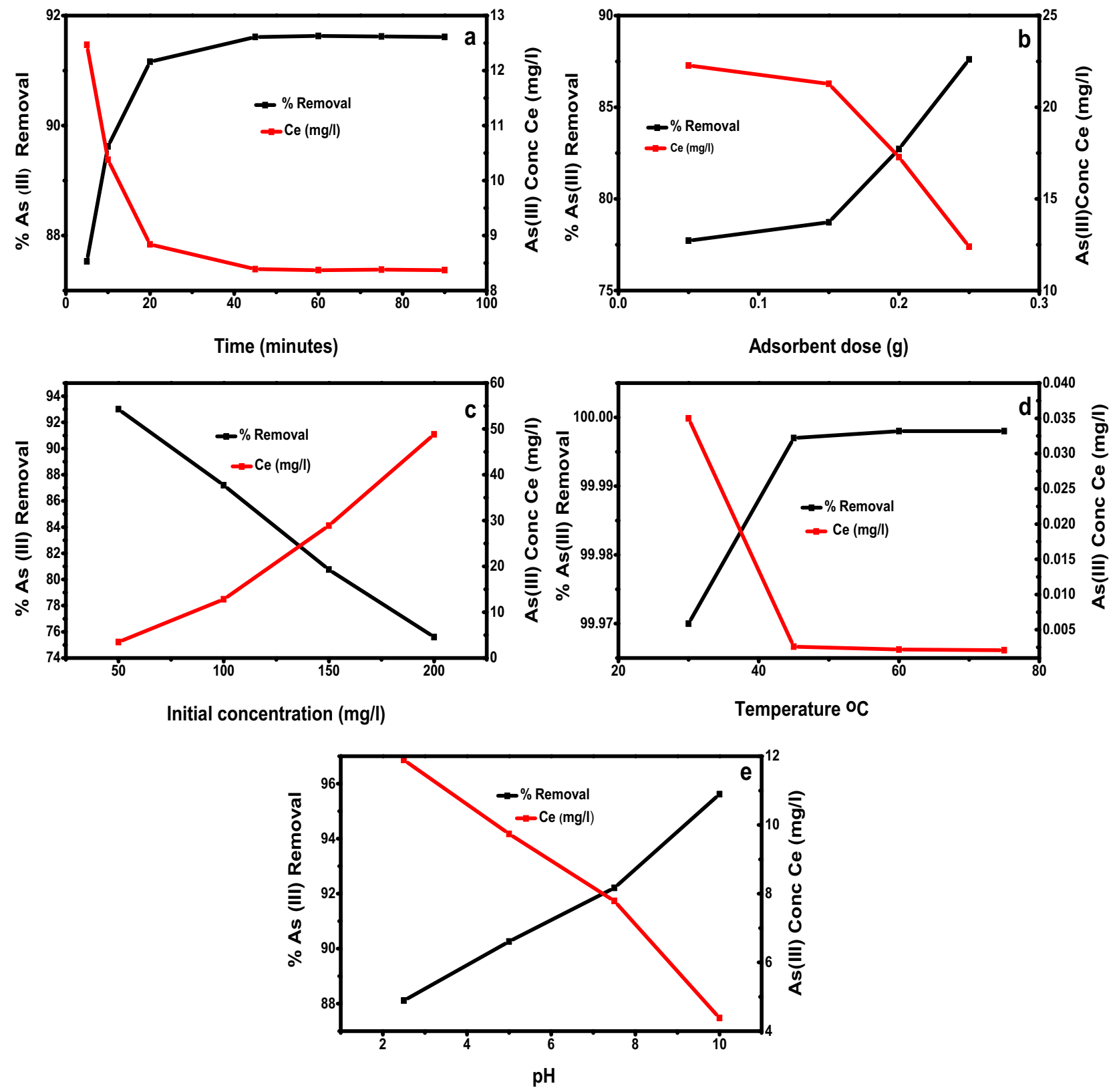

Fig. 3 Effect of a contact time ( $\mathrm{min}), \mathbf{b}$ adsorbent dose (g), c initial As(III) concentration ( $\mathrm{mg} / \mathrm{l})$, $\mathbf{d}$ temperature $\left({ }^{\circ} \mathrm{C}\right)$, e $\mathrm{pH}$ on $\% \mathrm{As}(\mathrm{III})$ removal by zinc chloride activated $D$. guineense seed shell

graph of $\mathrm{t} / \mathrm{q}_{\mathrm{t}}$ versus time ( $\mathrm{t}$ ) gave a straight line with $\mathrm{R}^{2}$ value of 0.9999 indicating that the adsorption of As(III) followed the pseudo-second order model.

\subsection{Adsorption isotherm results}

Adsorption isotherm explains the interaction of the adsorbate molecules between the liquid and the solid phase at constant temperature. The correlation between the equilibrium of arsenic(III) adsorbed and the solute concentration was studied using Freundlich, Langmuir and Tempkin which are frequently used adsorption isotherms. The studies were done at adsorbent dose of $0.1 \mathrm{~g}$ in $25 \mathrm{ml}$, temperature $30^{\circ} \mathrm{C}$, time of $25 \mathrm{~min}$, and at $\mathrm{pH} 6$ and initial concentration of 50-200 mg/l. The linearized form of the Freundlich, Langmuir and Tempkin are presented.

\subsubsection{Freundlich model (linear)}

The Freundlich isotherm is described by Eq. 6.

$\ln q e=\ln K_{f}+1 /\left(n \ln C_{e}\right)$

\section{SN Applied Sciences}


where Freundlich constants $\mathrm{K}_{\mathrm{f}}$ and $1 / \mathrm{n}$ are the adsorption capacity and adsorption intensity respectively given in Table 3. The values were derived from the linear plot of Inqe versus InCe and shown in Fig. 4a. "The degree of non-linearity between solution concentration and adsorption is $n$ dependent as follows: if the value of $n$ is equal to unity the adsorption is linear; if the value is below unity, this implies that the adsorption process is chemical; if the value is above unity, adsorption is a favourable physical process" [33]. In the present investigation the calculated value of $1 / \mathrm{n}$ was 0.447 indicating that it is valid for the active adsorption sites.

\subsubsection{Langmuir model (linear)}

The Langmuir isotherm which is based on a surface with homogeneous binding sites, equivalent sorption energies and no interactions between adsorbed molecules is expressed by Eq. 7 .

$\frac{C_{e}}{q_{e}}=\frac{C_{e}}{q_{\max }}+\frac{1}{q_{\max } K_{L}}$

where $C_{e}$ is the equilibrium concentration of arsenic(III) $(\mathrm{mg} / \mathrm{l}), q_{e}$ is the quantity of arsenic(III) adsorbed onto the adsorbent at equilibrium $(\mathrm{mg} / \mathrm{g}), q_{\max }$ is the maximum

Table 3 Isotherm constants for the adsorption of $\mathrm{As}$ (III) on zinc chloride activated $D$. guineense seed shell

\begin{tabular}{lll}
\hline Freundlich model & Langmuir model & Tempkin model \\
\hline $\mathrm{K}_{\mathrm{f}}(\mathrm{mg} / \mathrm{g})=6.740$ & $\mathrm{q}_{\max }(\mathrm{mg} / \mathrm{g})=48.077$ & $\mathrm{~B}=9.717$ \\
$1 / \mathrm{n}=0.447$ & $\mathrm{~K}_{\mathrm{L}}(\mathrm{l} / \mathrm{mg})=0.069$ & $\mathrm{~A}=0.860$ \\
$\mathrm{R}^{2}=0.998$ & $\mathrm{R}^{2}=0.991$ & $\mathrm{R}^{2}=0.984$ \\
& $\mathrm{R}_{\mathrm{L}}=0.127$ & \\
\hline
\end{tabular}

monolayer adsorption capacity of adsorbent $(\mathrm{mg} / \mathrm{g})$ and $K_{L}$ is the Langmuir adsorption constant $(\mathrm{L} / \mathrm{mg})$. The gragh of $C_{e} / q_{e}$ against $C_{e}$ gave a characteristic shape with a slope and intercept of $1 / \mathrm{q}_{\max }$ and $1 / \mathrm{q}_{\max } \mathrm{K}_{\mathrm{L}}$ respectively (Fig. $5 \mathrm{~b}$ ). $\mathrm{K}_{\mathrm{L}}$ is an important tool in the calculation of the dimensionless equilibrium parameters $\left(R_{L}\right)$ that explains favourability of the adsorption process. The adsorption is (1) unfavourable when $R_{L}>1$ (2) linear when $R_{L}=1$ (3) favourable when $0<R_{L}<1$ and (4) irreversible when $R_{L}=0$ [34]. $R_{L}$ is calculated using Eq. 8.

$R_{L}=\frac{1}{\left(1+K_{L} C_{0}\right)}$

\subsubsection{Tempkin model (linear)}

The Tempkin isotherm is based on linear decrease of heat of adsorption while ignoring extremely low and very high concentration. It is expressed by Eq. 9 .

$q_{e}=B \ln A+B \ln C_{e}$

where $\mathrm{q}_{\mathrm{e}}$ is the amount of adsorbate adsorbed at equilibrium $(\mathrm{mg} / \mathrm{g}) ; C_{e}$ is concentration of adsorbate in solution at equilibrium ( $\mathrm{mg} / \mathrm{l})$. $B$ is a constant related to the heat of adsorption and it is defined by the expression $B=R T / b, b$ is the Tempkin constant in $(\mathrm{J} / \mathrm{mol}), \mathrm{T}$ is the absolute temperature $(\mathrm{K}), \mathrm{R}$ is the gas constant $(8.314 \mathrm{~J} / \mathrm{mol} \mathrm{K})$, and $\mathrm{A}$ is the Tempkin isotherm constant $(\mathrm{l} / \mathrm{g})$. From the graph of $\mathrm{q}_{\mathrm{e}}$ versus $\ln C_{\mathrm{e}}$ (Fig. $5 \mathrm{C}$ ), $\mathrm{B}$ and $\mathrm{A}$ can be calculated from the slopes (B) and intercepts (BInA) respectively.

The Freundlich model (Fig. 5a) presented better fit with regression coefficient $\left(R^{2}\right)$ of 0.998 compared to the Langmuir isotherm (Fig. 5b) having $R^{2}$ of 0.991 and Tempkin (Fig. $5 \mathrm{C}$ ) isotherm having $\mathrm{R}^{2}$ of 0.984 . Thus the adsorption of $\mathrm{As}$ (III) onto zinc chloride activated $D$. guineense seed shell (ZDGSS) was not onto a uniform site only rather a
Fig. 4 a Pseudo first order, b pseudo second order plots of the adsorption of As(III) onto zinc chloride activated $D$. guineense seed shell
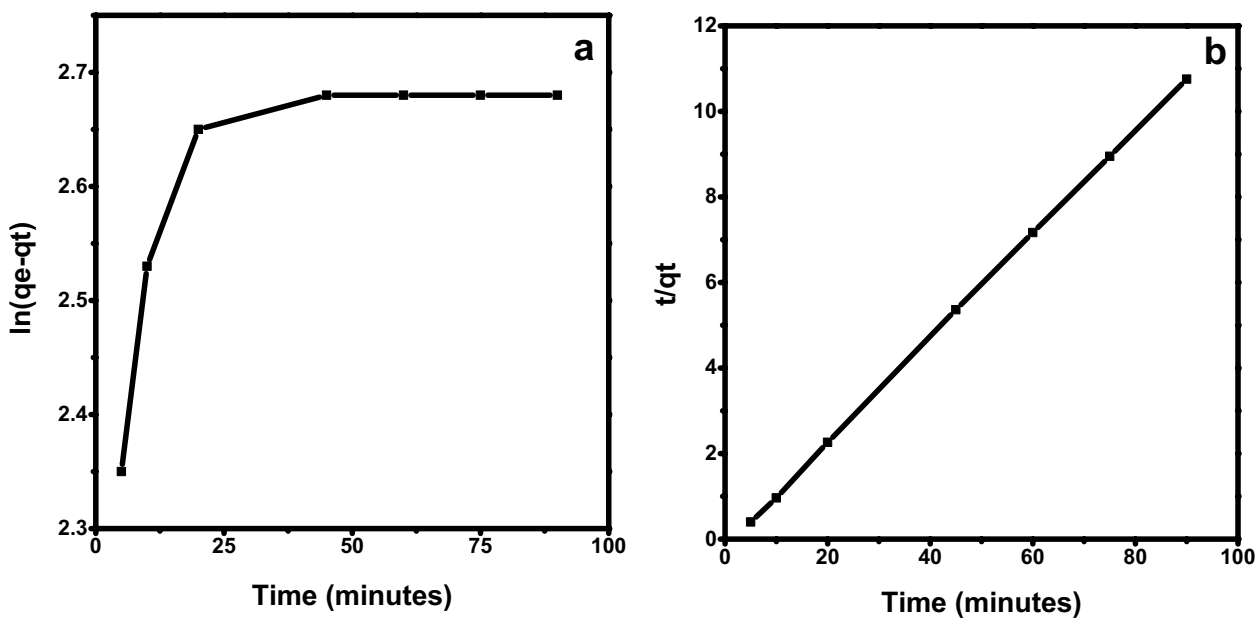

SN Applied Sciences A SPRINGER NATURE journal 

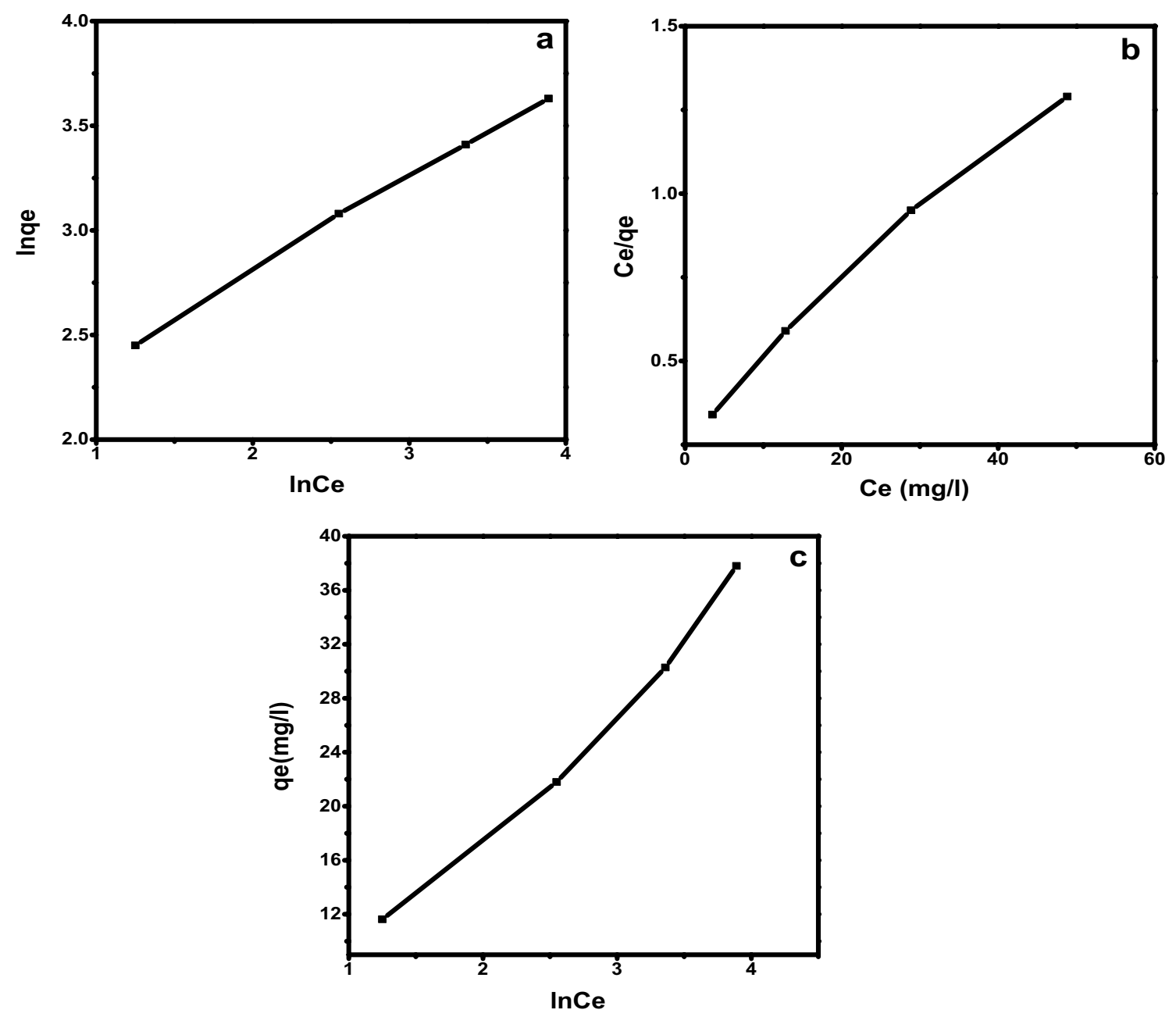

Fig. 5 a Freundlich, b Langmuir and c Tempkin isotherm for the removal of As(III) by zinc chloride activated D. guineense seed shell

multilayer adsorption occurred. However monolayer adsorption also played a very important role in the As(III) uptake onto ZDGSS ( $R^{2}$ for Langmuir is 0.991). The maximum monolayer adsorption capacity for the uptake of As(III) onto ZDGSS was obtained to be $48.077 \mathrm{mg} / \mathrm{g}$. Calculated $R_{L}$ value was less than 1 while the value of $n$ was greater than 1 (Table 3) hence adsorption was favourable physical process.

\subsection{Thermodynamic studies}

The relationship between equilibrium constant $\mathrm{K}^{\circ}$ and temperature is plotted in Fig. 6. Thermodynamic equilibrium parameters such as change in free energy $\left(\Delta \mathrm{G}^{\circ}, \mathrm{kJ} /\right.$ $\mathrm{mol})$, enthalpy $\left(\Delta \mathrm{H}^{\circ}, \mathrm{kJ} / \mathrm{mol}\right)$ and entropy $\left(\Delta \mathrm{S}^{\circ}, \mathrm{J} / \mathrm{mol} \mathrm{K}\right)$

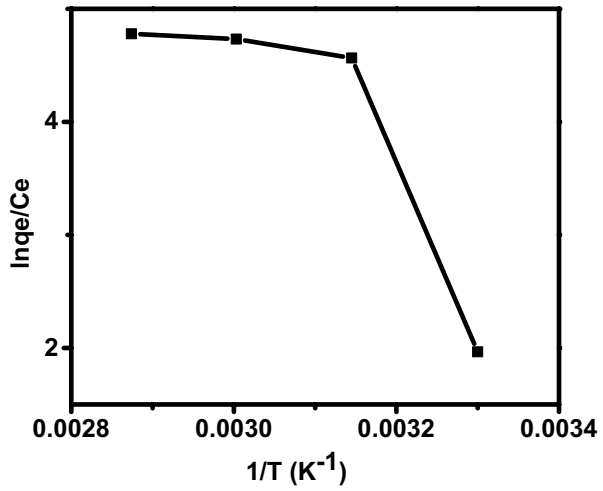

Fig. 6 Vant Hoff's plot of the adsorption of As(III) by zinc chloride activated $D$. guineense seed shell 
Table 4 Thermodynamic parameters for adsorption of As(III) on zinc chloride activated Dialium guineense seed shell

\begin{tabular}{ll}
\hline Temperature $(\mathrm{K})$ & $-\Delta \mathrm{G}^{\circ}(\mathrm{kJ} / \mathrm{mol})$ \\
\hline 303 & 179.88 \\
318 & 254.16 \\
333 & 314.55 \\
348 & 344.37 \\
\hline$\Delta \mathrm{H}^{\circ}(\mathrm{kJ} / \mathrm{mol})$ & $\Delta \mathrm{S}^{\circ}(\mathrm{J} / \mathrm{mol} \mathrm{K})$ \\
\hline 51.68 & 192.55 \\
\hline
\end{tabular}

were determined using the following Eqs. (10), (11) and (12).

$\Delta G^{\circ}=-R T \ln K^{\circ}$

$\ln K^{\circ}=\frac{\Delta S^{\circ}}{\mathrm{R}}-\frac{\Delta H^{\circ}}{R T}$

$K^{\circ}=\frac{q_{e}}{C_{e}}$

where $\mathrm{q}_{\mathrm{e}}$ and $\mathrm{C}_{\mathrm{e}}$ are the amount of arsenic(III) ion adsorbed per unit mass of adsorbent and concentration of arsenic(III) ion in aqueous phase at temperature $T(K)$. $R$ is the gas constant $(8.314 \mathrm{~J} / \mathrm{mol} \mathrm{K})$. The $\Delta H^{\circ}$ and $\Delta \mathrm{S}^{\circ}$ values (Table 4$)$ were obtained from the slope and intercept of Vant Hoff's plots of $\ln K^{\circ}$ vs $1 / T$ as shown in Fig. 6.

The positive and lower value of $\Delta \mathrm{H}^{\circ}(51.68 \mathrm{~kJ} / \mathrm{mol}<$ $80.00 \mathrm{~kJ} / \mathrm{mol}$ ) shows the endothermic nature of adsorption and the possibility of physical adsorption [35]. The change in entropy $\left(\Delta S^{\circ}\right)$ was positive, suggesting that the entropy increased during the adsorption showing the increased disorder at the solid solution interphase. The negative values of $\Delta G^{\circ}$ demonstrated that the adsorption process was spontaneous and the decrease of $\Delta G^{\circ}$ values with the increase of temperature indicated that the adsorption was more feasible at higher temperature. A comparison of adsorption capacities of different adsorbents for adsorption of As(III) was made and presented in Table 5. The zinc chloride activated $D$. guineense seed shell exhibited higher sorption capacity than most other sorbents.

\section{Conclusions}

In this work four activated carbons were prepared from D. guineense seed shell. The zinc chloride activated $D$. guineense seed shell gave the highest iodine value $(962.52 \mathrm{mg} / \mathrm{g})$ than the raw material and the other three activated carbons and was used successfully as adsorbing agent for the removal of As(III) from water. Contact time, adsorbent dose, temperature, initial As(III) concentration and $\mathrm{pH}$, influenced the adsorption. The maximum adsorption of As(III) occurred at alkaline, as adsorption increased with $\mathrm{pH}$. Removal efficiency increased with decreasing As(III) concentrations and increasing adsorbent dose. The Freundlich, Langmuir and Tempkin isotherm models were used to correlate the adsorption equilibrium of $\mathrm{As}$ (III) onto zinc chloride activated $D$. guineense seed shell. The data were in good agreement with both Freundlich $\left(R^{2}=0.998\right)$ and Langmuir $\left(R^{2}=0.991\right)$ isotherms, than the Tempkin isotherm $\left(R^{2}=0.971\right)$, the Freundlich model having a better correlation. Since $D$. guineense seed shell, an agricultural solid waste is locally available; its use as adsorbent is expected to be economical for industrial wastewater treatment. The results obtained from this project could be useful in the development of a treatment plant for arsenic polluted water.
Table 5 Comparison of adsorption capacities of different adsorbents for adsorption of As(III)

\begin{tabular}{lcc}
\hline Adsorbent & $\mathrm{q}_{\max }(\mathrm{mg} / \mathrm{g})$ & Reference \\
\hline Iron impregnated used tea activated carbon & 6.83 & {$[36]$} \\
Scoria & 0.19 & {$[37]$} \\
Acidithiobacillus ferrooxidans & & \\
BY-3 & 0.28 & {$[38]$} \\
Chitosan-coated biosorbent & 56.50 & {$[39]$} \\
Polymer/inorganic fibrous sorbent & 2.90 & {$[40]$} \\
Zirconium polyacrylamide hybrid material & 41.49 & {$[5]$} \\
Functionalized diatom silica shells & 49.21 & {$[1]$} \\
Zinc chloride activated Dialium guineense seed shell & 47.08 & This study \\
\hline
\end{tabular}




\section{Compliance with ethical standards}

Conflict of interest The authors declare that they have no conflict of interest.

\section{References}

1. Zhang J, Ding T, Zhang Z, Xu L, Zhang C (2015) Enhanced adsorption of trivalent arsenic from water by functionalized diatom silica shells. PLoS ONE 10:4. https://doi.org/10.1371/ journal.pone.0123395

2. Meng X, Bang S, Korfiatis GP (2000) Effect of silicate, sulphate and carbonate on arsenic removal by ferric chloride. Water Res 34:1255

3. Ghimire KN, Inoue K, Yamaguchi H, Makino K, Miyajima T (2003) Adsorptive separation of arsenate and arsenite anions from aqueous medium by using orange waste. Water Res 37:4945

4. Amin MN, Kaneco S, Kitagawa T, Begum A, Katsumata $H$, Suzuki T, Ohta K (2006) Removal of arsenic in aqueous solutions by adsorption onto waste rice husk. Ind Eng Chem Res 45:8105-8110

5. Mandal S, Sahu MK, Patel RK (2013) Adsorption studies of arsenic III removal from water by zirconium polyacrylamide hybrid material (ZrPACM-43). Water Resour Ind 4:51-67

6. Ayotte JD, Montgomery DL, Flanagan SM, Robinson KW (2003) Arsenic in groundwater in eastern New England: occurrence, controls and human health implications. Environ Sci Technol 37:2075

7. Chakravarty S, Dureja V, Bhattacharyya G, Maity S, Bhattacharjee $S$ (2002) Removal of arsenic from groundwater using low cost ferruginous manganese ore. Water Res 36:625

8. Shugi K, Singh TS, Pant KK (2003) Equilibrium and kinetic studies on removal of arsenite by iron oxide coated activated alumina. Indian J Environ Health 45:151

9. Ansari R, Sadegh M (2007) Application of activated carbon for removal of arsenic ions from aqueous solutions. Electron J Chem 4(1):103-108

10. Naba KM, Palas R, Shreya B, Biswajit D, Kousik D (2013) Removal of arsenic(III) and arsenic $V$ on chemically modified low-cost adsorbent: batch and column operations. Appl Water Sci 3:296-304

11. Egbinola CN, Amanambu AC (2014) Groundwater contamination in Ibadan, Southwest Nigeria. Springerplus 3:448

12. Rajan D, Talat M, Hasan S (2009) Rice polish: an alternative to conventional adsorbents for treating arsenic bearing water by upflow column method. Ind Eng Chem Res 48:10180-10185

13. Rahim M, Haris MRHM (2015) Application of biopolymer composites in arsenic removal from aqueous medium: a review. J Radiat Res Appl Sci 8:255-263

14. Chukwuemeka-Okorie HO, Ekemezie PN, Akpomie KG, Olikagu CS (2018) Calcined concob-kaolinite combo as new sorbent for sequestration of toxic metal ions from polluted aqua media and desorption. Front Chem 6:1-13

15. Akpomie KG, Dawodu FA, Eze SI, Asegbeloyin JN, Ani JU (2018) Heavy metal remediation from automobile effluent by thermally treated montmorillonite-rice husk composite. Trans R Soc S Afr 73:254-263

16. Gautam RK, Mudhoo A, Lofrano G, Chattopadhyaya MG (2014) Biomass derived biosorbents for metal ions sequestration: adsorbent modification and activation methods and adsorbent regeneration. J Environ Chem Eng 2:239-259

17. Lingamdinne LP, Chang YY, Yang JK, Singh J, Choi EH, Shiratani M, Koduru JR, Attri P (2017) Biogenic reductive preparation of magnetic inverse spinel iron oxide nanoparticle for the adsorption removal of heavy metals. Chem Eng J 307:74-84

18. Mohan S, Kumar V, Singh DK, Hasan SH (2017) Effective removal of lead ions using grapheme oxide-MgO nanohybrid from aqueous solution: isotherm, kinetic and thermodynamic modeling of adsorption. J Environ Chem Eng. https://doi.org/10.1016/j. jece.2017,03.031

19. Billy T, Puziah AL, Taufiq YH (2013) Physical preparation of activated carbon from sugar cane bagasse and corn husk and its physical and chemical characteristics. Int J Eng Res Sci Technol 2:1-14

20. Menkiti CM, Aneke CM, Ejikeme PM, Onukwuli OD, Menkiti NU (2014) Adsorptive treatment of brewery effluent using activated Chrysophyllum albidum seed shell carbon. Springerplus $3: 213$

21. Budinova T, Krzeniska M, Tsyntnarski B, Zachariasz J, Petrova B (2008) Activated carbon produced from bamboo pellets for removal of arsenic(III) ions from water. Bull Chem Commun 40(2):168-171

22. Nwadiogbu JO, Ajiwe VIE, Okoye PAC (2016) Removal of crude oil from aqueous medium by sorption on hydrophobic corncobs: equilibrium and kinetic studies. J Taibah Univ Sci 10:56-63

23. Abechi SE, Gimba CE, Uzairu A, Dallatu YA (2013) Preparation and characterization of activated carbon from palm kernel shell by chemical activation. Res J Chem Sci 3(7):54-61

24. Guan BTH, Latif PA, Yap TYH (2013) Physical preparation of activated carbon from sugarcane bagasse and corn husk and its physical and chemical characteristics. Int J Eng Res Sci Technol 2(3):1-14

25. Suziki RM, Andrade AD, Sousa JC, Rollenberg JC (2007) Preparation and characterization of activated carbon fro rice bran. Bioresour Technol 98:1985-1991

26. Gaur N, Kukreja A, Yadav M, Tiwari A (2018) Adsorptive removal of lead and arsenic from aqueous solution using soya bean as a novel biosorbent: equilibrium isotherm and thermal stability studies. Appl Water Sci 8:98

27. Kannan N, Sundaram MM (2001) Kinetics and mechanism of removal of methylene blue by adsorption on various carbonsa comparative study. Dyes Pigments 51:25-40

28. El-Sayed GO (2011) Removal of methylene blue and crystal violet from aqueous solutions by palm kernel fibre. Desalination 272:225-232

29. Akpomie KG, Dawodu FA, Adebowale KO (2015) Mechanism on the sorption of heavy metals from binary solution by a low cost montmorillonite and its desorption potential. Alexandria Eng J 54:757-767

30. Eze SI, Akpomie KG, Ezeofor CC, Mmadubuike NV, Ojo FK (2019) Remediation of oil spill polluted water from Niger Delta Nigeria by sorption onto ammonium sulphate modified Dialium guineense seed husk. Pet Sci Technol 37(15):1830-1838

31. Saleem M, Pirzada T, Quadeer R (2007) Sorption of acid violet 17 and direct red 80 dyes on cotton fibre from aqueous soltions. Colloids Surf A 292:246-250

32. Kadirvelu K, Namasivayan C (2003) Activated carbon from coconut coirpith as metal adsorbent: adsorption of $\mathrm{Cd}(\mathrm{II})$ from aqueous solution. Adv Environ Res 7:471-478

33. Kumar PS, Ramalingam S, Senthamarai C, Niranjanaa M, Vijayalakshmi P, Sivanesan S (2010) Adsorption of dye from aqueous solution by cashew nut shell: studies on equilibrium isotherm, kinetics and thermodynamics of interactions. Desalination 261:52-60

34. Akpomie KG, Onyeabor CF, Ezeofor CC, Ani JU, Eze SI (2019) Natural aluminosilicate clay obtained from South-Eastern Nigeria as potential sorbent for oil spill remediation. J Afr Earth Sci 155:118-123 
35. Zhang Y, Yu F, Cheng W, Wang J, Ma J (2017) Adsorption equilibrium and kinetics of the removal of ammoniacal nitrogen by zeolite X/activated carbon composite synthesized from elutrilithe. J Chem 2017:1-9

36. Mahmood T, Aslam M, Naeem A, Siddique T, Din SU (2018) Adsorption of As(III) from aqueous solution onto iron impregnated used tea activated carbon: equilibrium, kinetic and thermodynamic study. J Chil Chem Soc 63:1

37. Kwon JS, Yun ST, Lee JH, Kim SO, Jo HY (2010) Removal of divalent heavy metals ( $\mathrm{Cd}, \mathrm{Cu}, \mathrm{Pb}$ and $\mathrm{Zn}$ ) and arsenic(III) from aqueous solutions using scoria: kinetics and equilibria of sorption. $J$ Hazard Mater 174:307-313

38. Yan L, Yin H, Zhang S, Leng F, Nan W, Li H (2010) Biosorbent of inorganic and organic from aqueous solution by Acidithiobacillus ferrooxidans BY-3. J Hazard Mater 178:209-217
39. Boddu VM, Abburi K, Talbott JL, Smith ED, Haasch R (2008) Removal arsenic(III) and arsenic(V) from aqueous medium using chitosan-coated biosorbent. Water Res 42:633-642

40. Vatutsina OM, Soldatov VS, Sokolova VI, Johann J, Bissen M, Weisembachar A (2007) A new hybrid (polymer/inorganic) fibrous sorbent for arsenic removal from drinking water. React Funct Polym 67:184-201

Publisher's Note Springer Nature remains neutral with regard to jurisdictional claims in published maps and institutional affiliations. 